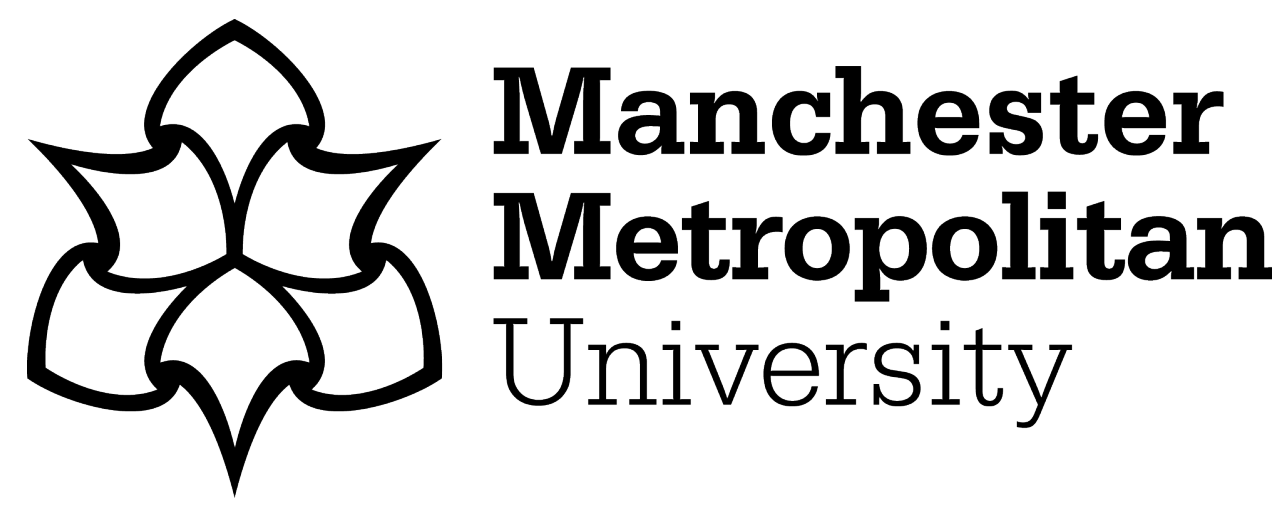

Harrison, Michaela (2019) Experimenting with data and analysis in researching the writing practices of student teachers. International Journal of Research and Method in Education, 43 (3). ISSN 1743-727X

Downloaded from: https://e-space.mmu.ac.uk/624149/

Version: Accepted Version

Publisher: Taylor \& Francis (Routledge)

DOI: https://doi.org/10.1080/1743727X.2019.1687668

Please cite the published version 


\section{Experimenting with data and analysis in researching the writing practices of student teachers}

Michaela J. Harrison

Faculty of Education, Manchester Metropolitan University

Brooks Building, 53 Bonsall Street, Manchester, M15 6GX.

Tel.: +441612472069

E-mail address: m.j.harrison@mmu.ac.uk 


\title{
Experimenting with data and analysis in researching the writing practices of student teachers
}

\author{
Primarily methodological in its orientation, this paper offers a presentation of \\ 'research outcomes' in ways that challenge and disrupt commonplace notions of \\ data and analysis. In an attempt to write against the grain of conventional \\ qualitative research practice and to experiment with alternative encounters with \\ data and analysis, I present 'data/analysis' in the form of a play (or imagined \\ performance) that writes into being two Deleuzo-Guattarian principles - the \\ critique of the self-conscious ' $I$ ' and desire. The play draws on a wider study that \\ examined the potential of writing as a tool for learning for undergraduate student \\ teachers in England. As such, the paper also contributes to debates on the practice \\ and purpose of writing as a method of (professional) inquiry.
}

Keywords: Deleuze; Guattari; writing; data; analysis, experiment

\section{Introduction}

Qualitative research is a diverse and continuously evolving site of inquiry (Torrance 2017). Impossible to define, it has continuously proliferated and developed as a field, as successive historical 'moments', 'waves' or 'turns' (Denzin and Lincoln 2018) have continued to add to the melting pot of ideas about what might constitute qualitative research. More recent ontological and conceptual developments (Koro-Ljungberg, Löytönen and Tesar 2018), have ensured that even those few taken-for-granted or familiar and common aspects of qualitative research as a practice and process have been subjected to critique and subsequently considered anew. Led by scholars such as St. Pierre, Koro-Ljungberg, MacLure, Mazzei and Jackson, and in the aftermath of 'the various "turns" that have convulsed the humanities and social sciences; poststructuralist, postmodernist... Deleuzian... posthumanist', this reimagining of qualitative research 
methodology has caused 'major upheavals' (Koro-Ljungberg, MacLure and Ulmer 2018, 462), leading to another intense period of transition in the field (Denzin and Giardina 2017). A defining feature of this particular transition is the questioning of some of the most basic, fundamental and familiar categories and concepts that explain and structure conventional qualitative research practice, for example; research questions, literature reviews, methods of data collection, data analysis (Lather and St. Pierre 2013) and even data itself (MacLure 2013). As a result, qualitative researchers can no longer assume these categories are simply the benign or a priori descriptors and practices of the research process.

This paper draws on and contributes to the growing body of work that has shaped (and to some extent defined) this contemporary challenge to the conventional wisdom of qualitative research practice. It is influenced by the work of scholars who critically examine our previously held assumptions as well those that offer innovative or alternative conceptions or practices of the methodological process. I also make use of the philosophy of Deleuze and Guattari - whose work has keenly influenced my empirical research (see Author 2017, Details Withheld for Peer Review) as well as my writing and thinking about qualitative research, methods and methodology more generally. The paper is both experiment and provocation; a way of responding to some of the questions raised in the 'upheavals' (specifically what counts as data and data analysis) as I purposefully write against the grain of conventional qualitative research practice and in doing so, test or play at the boundaries of what might constitute qualitative research. I have been particularly inspired by a series of questions posed by Mazzei (2013) designed to incite the researcher/writer/scholar to think of data as agentic. Rather than presupposing data an 'inert and indifferent mass' (MacLure 2013) 
that yields passively to the will of the researcher, Mazzei encourages us to instead think of data as having the ability to act upon as well as being subjected to action.

A more conventional approach, one that according to St. Pierre (2013), owes its dominance in qualitative research to the persistence and pervasiveness of 'latent positivism', assumes data are dormant. Such an approach sees data only brought temporarily to life by the researcher as they are "marshalled as "evidence", disciplined into categories, or incorporated into higher-order concepts' (Koro-Ljungberg, MacLure and Ulmer 2018, 463). The relationship between data and the researcher is unilateral. The researcher examines, orders, codes or categorises, the otherwise lifeless data. In other words, the researcher uses data to produce analysis, after which, its utility exhausted, the data recedes from view (Koro-Ljungberg, MacLure and Ulmer 2018). Mazzei's (2012) incitation is based on a different relationship; a bilateral relationship where the researcher is 'produced in a mutual becoming of analysis and representation with, in, through participants in research narratives, as movement passing through bodies that produce us as becoming selves'.

In this way, we are encouraged to rethink or reimagine the relationship and the distinction between data and analysis. Analysis is transformed; from and beyond 'data organisation' (Jackson and Mazzei 2018) to a process of becoming where the subjectivity of the researcher is constituted alongside, through and in, entanglements between data, theory, participants, research practices and so on. The researcher is no longer the sole arbiter of agency, capable of producing an arm's length analysis, and data 'cannot be thought of as mere social construction with no material footing in the world' (Koro-Ljungberg, MacLure and Ulmer 2018, 469). To aid the researcher interested in engaging in this kind of qualitative work, where data and analysis are 'done' differently, Mazzei (2013) offers a series of deceptively simple questions as 
provocations, two of which inspired this paper. 'What are the data doing?' and, 'How am I made by data?'

It is not my intention to suggest answers to Mazzei's questions; rather I regard the questions as enabling a response to a concern or quandary I share with Richardson (2000, 153); 'how does what we write, affect who we become?' If the ways we are supposed to write research remains an unexamined trope in our claims to/for authoritative knowing, then we become in Foucault's (1977) terms 'docile'. As Richardson (quoted in Richardson and St. Pierre 2018, 824) more recently explained; 'Who we are and what we can be... are tied to how a knowledge system disciplines itself and its members and to its methods for claiming authority over both the subject matter and its members'.

Experimental, transgressive (Davies 2009) and inventive writing (Taylor 2017) acts not only to broaden the field in terms of what might constitute qualitative research, but also serves as a means of expression for my own resistant act against docility, against 'being disciplined'. This is not to say that one treatment or conception of data and its relationship to analysis is necessarily preferable, better or more ethical than the other, (although these arguments have been made and will be discussed below). Rather that 'the other', or 'thinking and doing things differently' (Torrance 2017) is simply required to dislodge the hegemonic authority of one, over and above all else. To this end, the remainder of this paper is devoted to the task of knowing differently through thinking and writing data agentically. I proceed aware of the challenges associated with thinking and doing research differently (Cumming 2015). I am cognisant of the fact that uncoupling myself from the standard treatment of data for analysis involves a dedisciplining that requires method and practice executed with a highly improbable state 
of constant vigilance. (I make no assumptions of immunity to St. Pierre's 'latent positivism'.)

So, what might thinking and writing data agentically involve? What might it look like? Here I turn to Davies (2009) for inspiration and specifically their chapter 'Life in Kings Cross: A play of voices'. In the chapter, Davies attempts to experience and experiment with a Deleuzian approach to writing by 'bringing into being' two Deleuzian principles: the first, 'discarding the self-conscious "I"' and the second, 'writing on an immanent plane of composition' $(2009,198)$. Davies exemplifies how a writer/researcher might actively experiment with producing and conceiving of knowledge production differently. In doing so, Davies writes against the grain of dominant discourses, challenging the authorial voice of habitualised social science; a voice that runs the risk of colonising the lives of those that the research/er claims to know. As ostensibly a piece of ethnographic work, Davies embarks upon a process of coming to know a place, its people and the culture they have created there, without running the risk of exploiting its inhabitants, writing that place as her own or confining the place to a known set of quantifiable and static truths. Davies achieves this using fiction to animate the lives of people, so they are rendered no longer strange to the reader but neither possessed by, nor subservient to, the writer/researcher. Davies presents a play (written for radio) of fictional characters, each connected to an actual place in different ways. The play functions as both data and analysis. In short, fiction, as an expression of imagination, is used to generate a different kind of relation between researcher and researched (Caine and Steeves 2009, cited in Caine et al. 2017), data and analysis. In this version of ethnography, data and analysis, the researcher and the researched are co-produced. Of engaging in this process, Davies $(2009,198)$ writes; 'the 
writing itself thus opens up the writer to becoming what is not yet known and to what can never be contained in words, or completely known'.

It is interesting to note that, in line with Mazzei (2013), Davies also evokes 'becoming'. As Deleuze and Guattari explain, becoming is not, and should not be confused with progressing or regressing, imitating or identifying with. It is 'a verb all of its own. It does not reduce to or lead to appearing, being, equalling or producing' ([1987] 2004, 263). Rather, it is an open-ended process with no set duration, culmination or resolution; 'a state of pure openness to the movement of pure difference' (Roy 2003, 77). Becoming has a mysterious, ineffable quality. It grows and creeps in all directions, lacking a definitive, knowable form; constantly moving; transforming - 'the very dynamism of change' (Stagoll 2010, 26). In this paper, by rethinking the relationship, and the distinction between data and analysis and through thinking and writing data agentically, I too attempt to evoke becoming; to be open to what can never be contained in words, or completely known (Taylor 2017). In writing against the grain, I allow myself the opportunity to experience and experiment with becoming through difference; to interrupt the taken-for-granted, to try something out to see what happens and to attempt to create something new (Torrance 2017).

As in Davies' work, the method I employ to do this is to write into being two Deleuzian principles in the form of a play (or imagined performance). The first principle, I borrow directly from Davies: the discarding of the self-conscious 'I'. The second is desire. I explain both concepts before presenting the play. Preceding this, and to provide the empirical context for the study, I now outline the wider project from which this paper draws. 


\section{Outline of the wider project}

The research project, from which this paper draws, constituted an analysis, a subsequent reimagining and then a further analysis of the written work student teachers produce for assessment as part of a large initial teacher education programme, in England. The project specifically focussed on what St. Pierre (2000) describes as 'the technology of the essay' or what is commonly referred to in the parlance of teacher education in England - 'the assignment'. The 're-imagining' of the assignment involved the students reconceptualising text (writing) in the Deleuzo-Guattarian sense, as an agent that acts outside of itself (Alvermann 2000), and, assignment writing specifically, as a multiplicity of connections between people, places, things and other texts. I encouraged students to actively participate in this process of connectivity - to revel in it. As part of this process, they were permitted to select any form of text that allowed or encouraged them to think differently about the content of their writing, which in this case, was their own professional practice as student teachers. In doing so, students often chose popular culture texts, such as film or televised serials.

The study employed a classroom action research methodology, an approach that typically involves classroom teachers using qualitative methods of inquiry to make judgments about and improvements to their own practice (Kemmis and McTaggart 2000). It has increasingly however, been adopted by university-based practitioners, particularly teacher educators (Noffke and Somekh 2011), to do the same - as was the case here. At the time of the study, I was employed as a university-based teacher educator working predominately with undergraduate student teachers. The study aimed to develop my own understanding and practice of utilising writing as a tool for the professional development of student teachers. Institutional ethical approval for the project was sought and granted.

\section{Principle 1: Discarding the self-conscious ' $I$ '}


According to Davies, "discarding the self-conscious "I" is "integral to the process of opening oneself to difference and the movement of language, voice and subjectivity to the as-yet-unknown' $(2009,198)$. I liken the renunciation of this 'I' as an action similar to that of sanding a door or a piece of furniture before it is repainted or varnished. The sanding is a necessary preliminary process; it ensures a 'key' - fine cracks or fractures to which the new paint adheres. In writing, the 'I' that I (we, you) have claimed as our own, as one who knows itself and is known by others, as one that has an identity, is an 'I' to which agentic data and transgressive and experimental writing and research will not stick. This is because the self-conscious ' $I$ ' is the ' $I$ ' of the authorial voice of qualitative research; one which is 'dogged by the need to present itself as the one who knows, and in particular the one who knows authoritatively' (Davies 1996, quoted in Davies 2009, 199).

In submitting to the authorial voice, the researcher is subservient to the need to present what is already known and so the endeavour becomes one of convincing the reader to buy into the illusion that the world can be fixed from a single perspective (Davies 1996, cited in Davies 2009). In doing so, the productive value of the text is high, but (purposefully) obscured. In pondering my own, would-be liberation from the selfconscious 'I', Jackson and Mazzei (2008) offer much helpful guidance. They explain that the ' $\mathrm{I}$ ' is self-conscious when it is evoked unproblematically. So, for example, this ' $\mathrm{I}$ ' might emerge where the author attempts to present the illusion of an ' $\mathrm{I}$ ' that is the centre of events, who is able to see, decipher and know the world as a result of their presence within it. Following this, Jackson and Mazzei (2008) offer an alternative practice or perspective in the form of what they refer to as "the performative "I"'. This, they explain, is a becoming 'I'. Indeed, 'becoming' is the raison d'être of the performative 'I'. It is actively constructed in its attempts at truth telling. This 'I' cannot be known in advance. 
It is not stable. It unfolds within and without the act of narration. '[It] has the potential to produce evocative, ethical and failed practices that result in a telling with the potential to open the gaps and produce different knowing' (Jackson and Mazzei 2008, 314)

Deleuze ([1968] 2004) conceptualises this 'I' as a subject that embodies a series of processes and a place in which thoughts can emerge. It is an emergent 'I'; an exciting and hopeful 'I'. As a writer/researcher, in order that I might disrupt my own use of the self-conscious 'I' and become performative, I will need to exploit the limits of experience and experiment by positioning an ' $\mathrm{I}$ ' that is becoming through the telling (Jackson and Mazzei, 2008). I present this paper as an attempted embodiment of the performative 'I'.

As part of my classroom action research project, I wondered how the students themselves experience the practice and potential of writing as a site of/for professional inquiry. In (re)presenting the outcomes of this study, the conventional approach, as described above, would require I take data, perhaps some students' writing or interview transcripts and, from the perspective of one that 'knows', subject the data to analysis. Should I 'prove' a thesis as a result, all the better. Examples of this 'normal'(ised) (re)presentation are plentiful. For instance, in Elbaz-Luwisch (2002), where extracts of autobiographical writing are offered as units for analysis; their purpose, to provide 'further understanding' of writing's potential as a means of fostering professional growth. More recently, Parr et al. (2015) similarly offer excerpts of students' writing to provide the basis for the claim that storytelling is a productive means of exploring emerging professional identities. (For other examples, see Author 2017, Details Withheld for Peer Review; Hinchion and Hall 2016 and Parker 2010.) As an alternative, I will instead write data/analysis as a play or imagined performance. In doing so, my intention in respect to discarding the self-conscious ' $\mathrm{I}$ ' and realising its performative analogue, can be broken down as follows: 
- The play forefronts the act of writing by using fiction to animate the participants. Data is not mute nor inert and is not simply subjected to analysis. Analysis is not presented as 'real' or authoritative.

- The play presents (student teacher) writing as an assemblage rather than a discrete or singular entity that can be captured in/by/as data and typified, categorised or summarised in/by/as analysis. The intention is to render the entanglement less strange to both the writer (me) and the reader (you).

- My task as a writer is thus to see/hear/think the folds in the experiential/experimental fabric as I move through it and as I go on becoming with/in it (Davies 2009).

\section{Principle 2: Desire}

Described by Ross (2010a, 63) as a 'central term in Deleuze's philosophical lexicon', the concept of desire appears in several of Deleuze's published works and is developed more fully in his later collaborations with Guattari, in particular A Thousand Plateaus ([1987] 2004) (Goa 2013). To elucidate on the Deleuzo-Guattarian conception of desire, (and perhaps rather counter-intuitively), I begin not by explaining what their concept of desire is, but rather, what it is not (or, more precisely, what it is distinct to and different from). This is not a personal preference but rather in keeping with a Deleuzo-Guattarian approach: they regularly explain and elaborate upon their conception of desire, its character and function, via a series of counter-positions and counter-arguments. They do so against a traditional and arguably more common understanding of desire, popularised as it was by intellectual giants of exceptional influence; from Plato's philosophy, to Freud's psychoanalysis (the latter of which, Deleuze and Guattari are outspokenly, and sometimes, vehemently, critical toward [Goodchild 1996]). This version of desire is a 
largely negative conceptualisation - desire constitutes an impulse or affectation borne of fixating on what one lacks. In Freud's oedipal theory, the lack is characterised by wanton, libidinal and impotent desires (Ross 2010b) and is a source of disturbance. In Plato, desire is unruly, base and instinctual. The lack is an appetite or ambition. It is a lowerorder human faculty, at odds with and in need of control or 'cognitive redirection' by (higher-order) reason (Kahn 1987). Frustratingly, these desires can never be fulfilled because, put simply, there is always something more; or as Brown (2008) describes, 'a surplus', that cannot be acquired. As our circumstances change and our identities evolve, so do our motivations and agendas and, in turn, our wants and needs. The lack therefore resists stasis, and, as such, it cannot be fully understood, or satisfied.

Implicit in these traditional philosophical and psychoanalytical conceptions is a preoccupation/fascination with desire's manifest qualities. In short, the focus is on what desire $i s$ (it is wanton, libidinal, unruly, base and so on). Deleuze and Guattari's concept presents us with an alternative for thinking about and with desire as they shift the emphasis for thinking from what desire is, to what desire does. For them desire is agentic; it produces lived affect in the world and this is where their interests lie. They write: 'If desire produces, its product is real. If desire is productive, it can be productive only in the real world and can produce only reality' (Deleuze and Guattari [1984] 2004, 28).

This productivity is expounded further; in Deleuzo-Guattarian terms, it is 'assembled' or 'machined'. It is not a singular, isolatable event or entity, but rather a process of connectivity between objects, bodies, expressions qualities and territories (Livesey 2010). These connections have social implications for example; power, privilege; pleasure, pain; voice, silence; action, inaction. When we work with the concept of desire therefore (as writers, researchers, students, academics), our compulsion should not be towards defining what desire is, nor should we preoccupy ourselves with 
identifying what is lacking and hypothesising how this lack might be addressed, rather we should work to understand something of what desire itself is producing. We must devote ourselves to "understanding the interests that produce desire, and the interests that desire seeks to produce and/or protect, to ask the Deleuzian question, how does it work?' (Jackson and Mazzei 2012, 92).

This conception of desire is interesting to me for several reasons. I believe it is highly useful when considering both my own, as well as the writing practices of others and, in this case particularly, student teachers. For example, I wonder what interests produce desire as it is experienced by student teachers (when the practice of writing is understood as an assemblage) and how these interests are thus served by the affects that desire produces. For example, how does the 'knowledge system' (Richardson in Richardson and St. Pierre 2018) of university-based teacher education work to produce desire? And once forged, what does desire in this context then produce - what are its embodied or indeed, ethereal implications? (For as Ross [2010a, 67] explains, 'desire is a process in which anything is permissible'.)

This exploration of how desire might work in the assemblage of student teacher writing is important because it allows an insight into some of the different forces at work when students write as a means of professional inquiry. In other words, it guards against the naive assumption that writing for professional development is a process confined by the parameters of professional practice, professional identity and so on. It is, in Goodchild's words, a helpful digression or alternative 'that [carries] thought elsewhere, shattering the coherence of hegemonic discourses' $(1996,2)$. It is to acknowledge that much more is at work than what we intend when we, as teacher educators, design writing tasks for the purposes of fostering professional growth (ElbazLuwisch 2002) or exploring emerging professional identities (Parr et al. 2015). 
Deleuze's philosophy, and particularly the Deleuzo-Guattarian concept of desire, helps shift the focus from what is there (or at least, what we think is there), to what is (sometimes unexpectedly) being produced (Jackson and Mazzei 2012). The relationship between writing and professional development is not straightforward - writing as professional inquiry is not a binary composition. What is produced is not confined or limited to what at first might appear its constitutive elements (writing and professional practice or identities). Working with the concept of desire, enables us to glimpse at what else might be happening; the unexpected and potential implications and consequences of writing as a method of (professional) inquiry.

In writing the play, I will attempt to animate desire as a generated and generative force. I will not exemplify what desire is in relation to student teachers' writing. I will not identify what the student teachers lack or wish for (Brown 2008). Rather the play is intentioned as a response to the question of how desire might work (Jackson and Mazzei 2012) in the assemblage of student teacher writing. It is a method of rendering these (possible) workings visible without laying claim to authoritative knowledge. Perhaps it goes without saying that these 'possible workings' are not pure invention. They were assembled through the process of research as I worked through and with traditional forms of data (student's writing and interview transcripts) and tried to make sense of what happens or might happen when student teachers write as a means of professional inquiry (whilst I myself simultaneously wrote as a means of professional inquiry). They are glimpses of the ways in which I came to suspect desire was at play in the process.

\section{Preface to the play}

The characters and events in the play are fictional, although I have based them on actual students, the writing they produced and the entanglement between data/analysis, 
researcher/researched that I experienced as the study progressed. As such, the play is similar to 'semi-fiction' as described by Whiteman and Phillips (as quoted in Watson 2011), where empirical content is presented in 'make-believe' or imagined form for particular methodological purposes. Fictional methods have a long history in educational and social research (Gough 2008, cf. Walker 1981) and in keeping with the general principles of fiction or semi-fiction as method, in writing the play, I do not presume to know or aim to represent the real lives of the research participants (Clough 2002). I am not suggesting that what I write is what they actually experienced in undertaking writing activity. Rather (and departing here from the more usual approaches to fiction as method) the play writes into being two key Deleuzo-Guattarian principles, so that I might contemplate the practice of writing as a means of professional inquiry for student teachers; its potential as well as in what, who and where it might be constituted as a process of becoming. The play is not intended to function as data, and what follows is not data analysis. Although, given the problematisations and reconceptualisations of data from which this paper draws, the play might be considered, in Koro-Ljungberg and MacLure's words (2013) 'data-becoming'. My preferred descriptor is 'data/analysis'. Additionally, it is worth noting that the play is not intended to inform live performance. Rather, it is offered as an 'on-paper-only performance text' (Snyder-Young 2010). Therefore, and in keeping with Caine et al.'s (2017) view that fictionalisation can be a means by which the researcher engages their imagination to enrich understandings, I have purposefully referred to the play as an 'imagined performance'.

Finally, the reader should note in advance that the paper ends abruptly after the play. This is intentional. It is a resistive technique against the (representational) temptation to arrest the indeterminacy and flow of the play and the process of becoming with/in it, by 'swaddling' it in 'researcherly paratext' (Watson 2011). In other words, 
commenting, analysing and explicating the play, but arguably, at the same time, closing down an event that is intended to be open and connectable. That said, should the reader want for guidance on how to approach or frame thinking with or about the play, I offer the following questions as gentle recommendations. The questions attend to both the Deleuzo-Guattarian principles I am working with; the discarding of the self-conscious 'I' and desire. They reflect how I have seen/heard/thought through the folds of the data/analysis as an experiential and experimental process as I go on becoming with/in it (Davies 2009).

- How is the writing of student teachers as an assemblage constituted? What 'objects, bodies, expressions, qualities [and/or] territories' (Livesey 2010, 18) might be involved?

- Within the assemblage, how is desire working and what effects and affects does it or can it produce? How does that desire produce further connections and how do these form/contribute towards student teacher becoming?

- In the context of university-based teacher education, how is desire itself produced? What are its antecedents and what or whose interests does it serve or protect?

- Finally, how does the loss of the authorial voice of the researcher (who can see, decipher, know and explain the world) affect our reading of and engagement with the subject or focus of the research (student teacher writing as professional inquiry)?

\section{The Play}

Voice 1: The crocus have flowered. Their blousing, vivid blooms bob gently in the breeze, heralding the onset of spring. There is something energising about this time of 
year - imbued as it is with possibility. But we are a university town and so beneath the sweet and temperate notes that sing with the promise of fair weather and free time, a network of loners sit quietly indoors, in bedrooms and libraries, computer suites and studies, churning out words for the appraisal of others. This is a solitary activity and one that does not lend itself well to seasonal appreciation.

Emilia: Like a duck in water, the quietness of her writing is misleading. The infrequency and irregular rhythm of the tap, tap, tap on the desktop keys gives some indication of the ebb and flow of inspiration. She is in that place where the idea, the nub of the thing she is trying to achieve continues to escape her. She can almost feel it. An odd sensation, but if she concentrates hard enough she experiences her argument like a weight on and in her body: odd, but reassuring - at least she knows that it is there. In moments of lesser clarity, she imagines the thing as a cloud, a gas-like substance growing and shrinking, merging with other gases, too wispy and intangible to grasp. Frustratingly it escapes her. She is tired now of the contradictions that only become apparent when she puts fingers to keyboard - complexity and consistency; uncertainty and comprehensibility; originality and standardised criteria. She needs a break.

Wrapped up in a blue woollen blanket, she stares blankly out of the kitchen window into the garden beyond. A fracture; a fissure... her attention is drawn by the incongruent delicacy of the pale yellow daffodils against the overgrown hazard of their communal garden. Her gaze shifts to the blackish, grey gunk that clings to the base of the kitchen tap - it repulses her, but she resists the urge to wipe it away. This is a tea break only, two minutes, five at most, and then she will return to her desk and write more. She raises her eyebrows as she recalls herself yesterday googling the word procrastination. Today was not going to be one of those days. She would write. Why does nobody clean around the base of the taps? It takes a minute, maximum. 
Ethereal presence (Patch Adams MD): Communal living is one of life's joys.

Emilia: What nonsense. The kettle boils and as she pours she recalls the film scene that depicts life in the commune. She doesn't think she is that type. All that carping on about love and friendship and service, it was a bit much to stomach. Still, there was something joyful about the film. She wonders how many of her fellow students will choose Dead Poet's Society for the assignment she's working on now. Maybe she should have chosen it. There seemed to be a definite tendency towards that sort of thing... another thing to think about.

Voice 2: In another part of town, Louisa is taking a well-deserved break. In exactly eight minutes, she needs to start getting ready for work. She approaches 'relaxing' in these eight minutes with the kind of paradoxical intent that only those with too many things to accomplish in too little time might understand. She stares blankly at the television determined to 'unwind'.

Louisa: Tomorrow she will re-read the whole thing, decide which bits are awful and make changes. The day after, she will do the same. And so it will go on. But for now, she will bask in its completeness - beginning, middle and end. If she didn't have work, she would go out and celebrate. As it is, the sense of accomplishment is enough to sustain merriment for, she hopes, the rest of the evening. She blinks and realises she is watching adverts. She sits up and scans the room for the remote, seeing her phone instead she chooses to update her status; 'Another 700 words in the bag and first draft complete. Happy!'

Emilia: She sits down again. A quick glance at her phone alerts her to the fact that others are clearly making better progress. Shit, she needs to focus or this thing will never get written. She scans the bullet points of her next section and suddenly she's captured it 
again. The pieces briefly coagulate and she hastens to write them in before they dissolve again. This bit is sounding $\mathrm{OK}$.

She writes.

She likes this idea. It wasn't hers, as it happens. Another student in her discussion group can lay claim to ownership, but good teaching and learning is collaborative - isn't it? The focus of her assignment, Sam 'the naughty pupil', doesn't mind his label! What a simple idea. Why had it not occurred to her before? She had, up until that moment, thought of him only in terms of a victim - wrongly accused and blamed for playground misdemeanours because he was an easy target. She glances down the page at the half written, jumbled mass of notes and quotations she made before calling time on her endeavours yesterday. There is something exciting there, the precise details of which she's not yet sure about - she hasn't written them yet, but the thought is nearly there, somewhere in and between those bullet points, written in red.

...Maybe Sam doesn't care about his label. Perhaps his naughtiness is a construction; a product of the need to cast someone in that role.

Voice 1: The idea allows just enough give in the thought process for a rupture to appear. The gunk around the taps... communal/shared living... bloody Patch Adams.

Ethereal presence (Patch Adams MD): If Patch was going to interrupt with anything now it would be to remind you to have joy in the task at hand. 
Voice 1: Ironic, as whilst writing is certainly a process full of affective sensation, the writer would be hard-pressed to describe it as joyful.

Ethereal presence (Patch Adams MD): Regardless, joy and goofiness are a credo...

Voice 1: ...of sorts.

Emilia: Joy and goofiness; the prospect of either seemed an eternity away. But there was something else she took from the film that was slightly less sickly sweet and she thought of it now. It wasn't the words of wisdom from Patch himself that she recalled but a striking visual; a product of crafty camera work recreating perspective that can trick the eye and the mind. Now, what was it again?

Voice 1: Emilia recalls a scene from the film in which two patients at a mental healthcare facility sit and talk. One of the patients, an elderly man, displays erratic and repetitive behaviour. Repeatedly he asks his fellow patient, Patch, 'how many fingers?' but scolds him despite his apparently correct response of 'four', as he holds four fingers aloft. In a moment of kindness the bad tempered patient offers Patch Adams a clue; 'look beyond the problem'. Taking his advice literally, Patch looks beyond the fingers held up in front of him. The fore image blurs and the four fingers appear as five. The old man repeats the question; 'how many fingers?' 'Five,' replies Patch, and the old man is elated.

Emilia: Looking past the problem is a philosophy surely worthy of a teacher who cares for her children. If nothing else, she knows how often and with how much force this principle has been explicated within the cosy confines of the university. With no children present to test resolve or good intention, she has certainly been caught up in the rhetoric. Perhaps this is worth mentioning. Think on Emilia, could this be my Dead Poet's? 
Voice 2: Readying herself for work, Louisa applies mascara. She drags the brush through her eyelashes. Just the right amount of pressure and speed coats thinly and evenly. For a moment, the repetitive motion is stupefying. A fraction of a second passes, she blinks and she's back, thinking and feeling in the moment again. She thinks of the women and girls made (in)famous by My Big Fat Gypsy Wedding. She is supposed to be fascinated by their difference, but she has concluded that the difference is slight (relatively speaking). The range is far smaller than we like to believe.

Regardless, today that difference has been a gift and she is thankful for their utility; she has written them; their difference from sameness, into her assignment.

Louisa: She thinks back to her university sessions and a sense of loss passes through her. She suddenly, and briefly, feels hollow. She recalls how the uncertainty and intensity of the experience brought them together. She knows she will miss it. She is proud though of the end product but god, she hopes it was worth it. She will never be that student who doesn't care how other people judge her; her work. She knows she gleans confidence from the approval of others - she doesn't feel bad about this, indeed she has long suspected that learning to teach has encouraged this facet of her behaviour. She knows she made that argument well in her writing and, you know what, she has convinced herself of it. She knows that is not enough, it's not the end game, but for now, she'll take it.

Voice 1: Emilia's hands hover over her keyboard. She can't afford another detour or to lose any more time. Deadlines are looming and she needs to be decisive about what gets in; she doesn't need another idea, she is clearly behind others - statements of jubilation on Facebook are a long way off for her. But she knows of her tutor's propensity for this kind of stuff. The idea is hers and she likes it, but she questions whether it is the right 
thing for her or her reader. The threads of her argument are slowly, painfully weaving themselves together but she is frustrated by her lack of finger to keyboard action.

Writing is about word count; this is not the time for ideas...

She weighs up her options, glancing first at the onscreen time display and then the word count; both stubbornly obstinate reminders of her lack of progress. In that moment, she feels a weight settle in her stomach. She stands up and goes to the window; she can't see the daffodils from here, just the tangle of shrubs, waste bins and decaying litter. What a mess. Communal living - what a joke.

Louisa: The front door closes behind her and as she unlocks the car (manually; it is very old). She notices the ever so slight tinge of warmth in the air. Working evenings is slightly more agreeable in this weather, either extreme is an irritant; too warm and sunny and the bar fills to bursting with happy-go-lucky patrons; too cold and she faces the prospect of being stranded in town when the car refuses to start for her journey home. It starts now. This day has been productive.

Funding: This research received no specific grant from any funding agency in the public, commercial, or not-for-profit sectors.

References:

Alvermann, Donna. E. 2000. "Researching libraries, literacies, and lives: A rhizoanalysis." In Working the Ruins: Feminist poststructural theory and methods in education, edited by Elizabeth A. St. Pierre, and Wanda S. Pillow, 114-129. New York, NY: Routledge.

Author, A. 2017. Details Withheld for Peer Review.

Brown, Tony. 2008. "Desire and Drive in Researcher Subjectivity: the broken mirror of Lacan." Qualitative Inquiry 14 (3): 402-423. https://doiorg.ezproxy.mmu.ac.uk/10.1177\%2F1077800407311960 
Caine, Vera, M. Shaun Murphy, Andrew Estefan, D. Jean Clandinin, Pamela Steeves, and Janice Huber. 2017. "Exploring the Purposes of Fictionalization in Narrative Inquiry." Qualitative Inquiry 23 (3): 215-221. doi:10.1177/1077800416643997.

Clough, Peter. 2002. Narratives and Fictions in Educational Research. Buckingham, UK: Open University Press.

Cumming, Tamara. 2015. "Challenges of 'thinking differently' with rhizoanalytic approaches: a reflexive account." International Journal of Research and Method in Education 38 (2): 137-148. doi: 10.1080/1743727X.2014.896892.

Davies, Bronwyn. 2009. "Life in Kings Cross: A play of voices.: In Voice in Qualitative Inquiry: Challenging conventional, interpretive and critical conceptions in qualitative research, edited by Alecia Y. Jackson, and Lisa. A. Mazzei, 197-219. New York, NY: Routledge.

Deleuze, G. (1968) 2004. Difference and Repetition. Reprint, London UK: Continuum International Publishing Group.

Deleuze, G., and F. Guattari. (1984) 2004. Anti-Oedipus. Reprint, London, UK: Continuum International Publishing Group.

Deleuze, G., and F. Guattari. (1987) 2004. A Thousand Plateaus: Capitalism and schizophrenia. Reprint, London, UK: Continuum International Publishing Group.

Denzin, Norman K., and Michael D. Giardina. 2017. "Introduction.” In Qualitative Inquiry in Neoliberal Times, edited by Norman K. Denzin, and Michael D. Giardina, 1-16. Oxon, UK: Routledge.

Denzin, Norman K., and Yvonna S. Lincoln. 2018. "Introduction: The Discipline and Practice of Qualitative Research." In The SAGE Handbook of Qualitative Research. $5^{\text {th }}$ ed., edited by Norman K. Denzin, and Yvonna S. Lincoln, 1-26. Thousand Oaks, CA: Sage Publications.

Elbaz-Luwisch, Freema. 2002. "Writing as Inquiry: Storying the Teaching Self in Writing Workshops." Curriculum Inquiry 32(4): 403-428.

Foucault, Michel. 1977. Discipline and Punish: The birth of the prison. Harmondsworth, UK: Penguin.

Goa, Jihia. 2013. “Deleuze’s Conception of Desire.” Deleuze Studies 7(3): 406-420. https://www-euppublishingcom.ezproxy.mmu.ac.uk/doi/pdfplus/10.3366/dls.2013.0120 
Goodchild, Phillip. 1996. Deleuze and Guattari: An introduction to the politics of desire. London, UK: Sage Publications.

Gough, Noel. 2008. "Fictional Writing." In The SAGE Encyclopaedia of Qualitative Research Methods. Volume 1, edited by Lisa Given, 338-340. Thousand Oaks, CA: Sage Publications.

Hinchion, Carmel and Kathy Hall. 2016. "The uncertainty and fragility of learning to teach: a Britzmanian lens on a student teacher story." Cambridge Journal of Education 46 (4):417-433. Doi:10.1080/0305764X.2015.1064095.

Jackson, Alecia Y., and Lisa A. Mazzei. 2008. "Experience and "I" in autoethnography: a deconstruction.” International Review of Qualitative Research 1 (3): 299-318. http://irqr.ucpress.edu/content/1/3/299

Jackson, Alecia Y., and Lisa A. Mazzei. 2012. Thinking with Theory in Qualitative Research: Viewing data across multiple perspectives. Oxon, UK: Routledge.

Jackson, Alecia Y., and Lisa A. Mazzei. 2018. "Thinking With Theory: A New Analytic for Qualitative Inquiry.” In The SAGE Handbook of Qualitative Research. $5^{\text {th }}$ ed., edited by Norman K. Denzin, and Yvonna S. Lincoln. 717-737. Thousand Oaks, CA: Sage Publications.

Kahn, Charles. H. 1987. "Plato's Theory of Desire." The Review of Metaphysics 41 (1): 77-103. http://www.jstor.org.ezproxy.mmu.ac.uk/stable/20128559.

Kemmis, Stephen and Robin McTaggart. 2000. "Participatory Action Research." In The SAGE Handbook of Qualitative Research. $2^{\text {nd }}$ ed., edited by Norman K. Denzin, and Yvonna S. Lincoln. 567-605. Thousand Oaks, CA: Sage Publications.

Koro-Ljungberg, Mirka, and Maggie MacLure. 2013. "Provocations, Re-Un-Visions, Death, and Other Possibilities of "Data."” Cultural Studies $<=>$ Critical Methodologies 13 (4): 219-222. doi:10.1177/1532708613487861.

Koro-Ljungberg, Mirka, Maggie MacLure, and Jasmine Ulmer. 2018. D...a...t...a..., Data++, Data, and Some Problematics." In The SAGE Handbook of Qualitative Research. $5^{\text {th }}$ ed., edited by Norman K. Denzin, and Yvonna S. Lincoln. 462484. Thousand Oaks, CA: Sage Publications.

Koro-Ljungberg, Mirka, Teija Löytönen, and Marek Tesar. 2018. "Introduction: Multiplicities of Data Encounters." In Disrupting Data in Qualitative Inquiry. Entanglements with the Post-Critical and Post-et Anthropocentric, edited by Mirka Koro-Ljungberg, Teija Löytönen, and Marek Tesar, 1-9. New York, NY: Peter Lang Publishing, Inc. 
Lather, Patti, and Elizabeth A. St. Pierre. 2013. "Post-qualitative research."

International Journal of Qualitative Studies in Education 26 (6): 629-633. doi: 10.1080/09518398.2013.788752.

Livesey, Graham. 2010. “Assemblage.” In The Deleuze Dictionary, edited by Adrian Parr, 18-19. Edinburgh, UK: Edinburgh University Press.

MacLure, Maggie. 2013. "Researching without representation? Language and materiality in post-qualitative methodology." International Journal of Qualitative Studies in Education 26 (6): 658- 667. doi: 10.1080/09518398.2013.788755.

Mazzei, Lisa. A. 2012. Summer Institute in Qualitative Research Keynote Presentations: Abstracts. ESRI. Available at: http://www.esri.mmu.ac.uk/siqr/keynotes13/mazzei.php

Mazzei Lisa. A. 2013. "Posthuman Enactments of Vibrant Data." Paper presented at Manchester: Manchester Metropolitan University's ESRI Summer Institute in Qualitative Research, Manchester, UK, July $22-26$.

Noffke, Susan and Bridget Somekh. 2011. "Action Research". In Theory and Methods in Social Research. $2^{\text {nd }}$ ed., edited by Bridget Somekh and Cathy Lewin, 94101. London: Sage Publications.

Parker, Darlene Ciuffetelli. 2010 "Writing and becoming [a teacher]: Teacher candidates' literacy narratives over four years." Teaching and Teacher Education, 26 (6): 1249-1260.

Parr, Graham, Scott Bulfin, Renee Castaldi, Elisabeth Griffiths, and Charmaine Manuel. 2015. 'On not becoming 'a mere empirical existence': exploring 'who' and 'what' narratives in pre-service English teachers' writing." Cambridge Journal of Education 45 (2): 133-148. doi: 10.1080/0305764X.2014.930416

Richardson, Laurel. 2000. "Skirting a Pleated Text: De-disciplining an academic life." In Working the Ruins: Feminist poststructural theory and methods in education, edited by Elizabeth A. St. Pierre, and Wanda S. Pillow, 153-163. New York, NY: Routledge.

Richardson, Laurel, and Elizabeth A. St. Pierre. 2018. "Writing: A Method of Inquiry." In The SAGE Handbook of Qualitative Research. $5^{\text {th }}$ ed., edited by Norman K. Denzin, and Yvonna S. Lincoln. 818-838. Thousand Oaks, CA: Sage Publications. 
Ross, Alison. 2010a. "Desire.” In The Deleuze Dictionary, edited by Adrian Parr, 6567. Edinburgh, UK: Edinburgh University Press..

Ross, Alison. 2010b. "Psychoanalysis: family, Freud and unconscious." In The Deleuze Dictionary, edited by Adrian Parr, 217-221. Edinburgh, UK: Edinburgh University Press.

Roy, Kaustuv. 2003. Teachers in Nomadic Spaces: Deleuze and Curriculum. New York, NY: Peter Lang Publishing, Inc.

Snyder-Young, Dani. 2010. "Beyond 'an Aesthetic of Objectivity': Performance Ethnography, Performance Texts, and Theatricality." Qualitative Inquiry 16 (10): 883-893. doi: 10.1177/1077800410383119.

St. Pierre, Elizabeth A. 2000. "Nomadic Inquiry in the Smooth Spaces of the Field: A Preface." In Working the Ruins: Feminist poststructural theory and methods in education, edited by Elizabeth A. St. Pierre, and Wanda S. Pillow, 258-283. New York, NY: Routledge.

St. Pierre, Elizabeth Adams. 2013. "The appearance of data." Cultural Studies $<=>$ Critical Methodologies 13 (4): 223-227. doi: 10.1177/1532708613487862.

Stagoll, Cliff. 2010. “Becoming.” In The Deleuze Dictionary, edited by Adrian Parr, 25-27. Edinburgh, UK: Edinburgh University Press.

Taylor, Carol A. 2017. "Rethinking the empirical in higher education: postqualitative inquiry as a less comfortable social science." International Journal of Research and Method in Education 40 (3):311-324. doi: 10.1080/1743727X.2016.1256984.

Torrance, Harry. 2017. “Experimenting with Qualitative Inquiry.” Qualitative Inquiry 23 (1): 69-76. doi:10.1177/1077800416649201.

Walker, Robert. 1981. "On the Uses of Fiction in Educational research - (and I don't mean Cyril Burt).” In Practising Evaluation, edited by David Smetherham, 147165. Driffiel, UK: Nafferton Books.

Watson, Cate. 2011. "Staking a small claim for fictional narratives in social and educational research." Qualitative Research 11 (4): 395-408. doi: $10.1177 / 1468794111404317$. 
